2. Kozub V.P. Napryami pidvichennya rezultativnosti vzaemodii organiv derzavnoi vladi I miscevogo samovryaduvannya $v$ realizacii vladnih povnovazen // Actualni problemi derzavnogo upravlinnya. 2011. № 1(41). povnovazen

3. Kolomoec T.O. Antikorupziyni obmegennya dlya osib, upovnovazenih na vikonannya funkciu derzavi abo miczevogo samovryaduvannya: realii vikoristannya filtru pravovoi viznacenosti v Ukraini $1 /$ Actualni problem vitchiznyanoi urisprudencii. 2019. № 5. P. 84-89.

4. Pankratova V.O. Znachennya principu pravovoi viznachenosti pri zdiysnenni publichnoi vladi// Zbirnik tez IV Miznarodnoi naukovo-praktichnoi conferencii, prisvyachenoi svitliy pamiati doctora yuridichnih nauk, profesora, akademika-pfsnovnika NAPRNU, pershogo golovi Constituziynogo Sudu Ukraini Leonida Petrovicha Yuzkova. 2-6 bereznya 2021 r. Khmelnizkiy. 580 p. pp.405-407.

5. Panushnik O.V. Administrativno-teritorialnareforma yak chinnik $z$ micnennya miscevoi economiki//Innovaciyna economica.2014. № 3. P. 76-83.

6. Petrishina M.O. Napryami udoskonalennya normotvorchosti v organah miscevogo samovryaduvannya v Ukraini // Evropeiski perspectivi. 2012. №2. p. 2. P. 71-76.

7. Pilipiv V.I. Pravo na sluzbu $v$ organah miczevogo samovryaduvannya: osnovi reglamentacii // Pravovi noveli. 2021. T.1. № 13. P.74-80.

H. Ostapenko, PhD (Law), Associate Prof.

Taras Shevchenko National University of Kyiv, Kyiv, Ukraine
8. Prichodko H.V. Decentralizacia publichnoi vladi ta misceve samovryaduvannya: conzeptualni pravovi pitannya // Chasopis Kuivskogo Universiyeyu prava. 2014 № 4. P. 71-74.

9. Rishennya Cherkaskogo okruzhnogo administrativnogo sudu № 580/577/21. Rezhim dostupu: https://reyestr.court.gov.ua/Review/95898263.

10. Sambor M.A. Organi miscevogo samovryaduvannya yak obyecti spovishcennya pro namir zdiysnennya prava na svobodu mirnich zibran // Visnyk LDUVS im. E.O. Didorenka. 2019. Vupusk. 3(87). P. 70-86.

11. Fedorenko V. Prinzip miscevogo samovryaduvannya $\vee$ Ukraini: ponyattya, zmist I systema// Istoriko-pravoviy chasopis. 2017. № 2(10). P. 43-49.

12. Furatov V.S. Udoskonalennya mechanizmu vzayemodii organiv vikonavchoi vladi I miscevogo samovryaduvannya na suchasnomy etapi derzhavotvorennya // Naukovi praci, derzavne upravlinnya, politologiya. Tom 130. Vipusk 117. P. 66-70.

13. Chernetska O.V. Predstavnizki organi miscevogo samovryaduvannya $\mathrm{v}$ sistemi publichnoi vladi: constituziyno-pravova priroda// Chasopis Kuivskogo Universiyeyu prava. 2010. № 2. P. 119-123.

Received: $29 / 09 / 2021$ Accepted: $15 / 10 / 2021$

\title{
LEGAL CERTAINTY IN THE ASPECT OF LOCAL GOVERNMENT
}

The article addresses the analyses of adherence to the legal certainty principle while the local government exercises its powers, which are enlarged during the reform of decentralization. It is stated that while the powers belonged to state government, the adherence of the legal certainty principle was found as very important to protect citizens from unpredictable and unequal treatment. So as soon as the powers were handed over to local government the protection of legal certainty principle still remains actual. Legal certainty requires clarity and legibility of legal provisions, limitation of discretive powers, promulgation and publication of legal acts in advance etc. These elements must be adhered realizing local powers.

One of the elements legal certainty requires is protection of the legitimate expectations of citizens. A number of court decisions which are analyzed in the article prove that breaking of legitimate expectations happens frequently. Emphasis is made on preventing such practices and on the need to respect legal certainty as a mandatory requirement of the rule of law.

The necessity of observance of the requirements of legal certainty at promulgation of acts by local self-government bodies and making the citizens know about them is determined.

Keywords: local self-government, legal certainty,certainty of law, rule of law, decenralization.

Bulletin of Taras Shevchenko National University of Kyiv.

Legal Studies, 2021; 4 (119): 63-69

удК 346.2; 347.1

DOI: https:doi.org/10.17721/1728-2195/2021/4.119-12
ISSN 1728-2195

(C) Taras Shevchenko National University of Kyiv, Publishing center "Kyiv University", 2021

П. О. Повар, канд. юрид. наук, доц. ORCID ID: 0000-0002-2057-5528

Київський національний університет імені Тараса Шевченка, Київ, Україна

\section{ПРАВОВЕ РЕГУЛЮВАННЯ ПРИПИНЕННЯ ФІЗИЧНОЇ ОСОБИ-ПІДПРИЄМЦЯ: ПОНЯТІЙНО-ТЕРМІНОЛОГІЧНІ ПРОБЛЕМИ}

Важливим елементом правового статусу фізичної особи-підприємця є умови позбавлення її статусу підприємця. Метою статті є визначення обсягу та змісту понятійно-термінологічного апарату правового регулювання припинення фізичної особи-підприємия, вироблення теоретичних положень і пропозицій щодо вдосконалення законодавств і практики правозастосування. Методологія дослідження ґрунтується на використанні історичного, системного, структурного методів, методів аналізу, синтезу й інших формально-логічних процедур.

У результаті дослідження історичного становлення законодавства України визначено та висвітлено логічний ряд розвитку понятійно-термінологічного апарату законодавчих актів. Обґрунтовано необхідність закріплення у кодифікованому акті у сфері підприємництва загальних положень щодо позбавлення статусу підприємця фізичною особою, зокрема і вживання відповідної термінології та понять. Сформульовано пропозиції щодо доповнення ГК України нормою щодо втрати фізичною особою статусу підприємця. Здійснено розмежування та встановлено співвідношення між поняттями "припинення підприємницької діяльності фізичною особою", "позбавлення статусу підприємця фізичною особою", "припинення фізичної особи-підприємия", "припинення суб'єкта господарювання". Досліджено та сформульовано положення щодо правової природи факту припинення підприємницької діяльності та факту позбавлення статусу підприємия фізичною особою. Визначено й обгрунтовано недоліки норм чинного законодавства, у яких не розмежовуються підстави припинення діяльності різної правової природи.

Запропоновано замінити термін "державна реєстрація припинення підприємницької діяльності фізичною особою" на термін "державна реєстрація позбавлення статусу підприємця фізичною особою" і внести відповідні зміни у законодавстві України. Обґрунтовано недоцільність вживання терміну "ліквідація" щодо фізичної особи-підприємия. Сформульовано визначення поняття "припинення фізичної особи-підприємця". Визначено можливість вживання поняття "позбавлення статусу підприємця фізичною особою" у вузькому та широкому значеннях.

Ключові слова: припинення підприємницької діяльності, фізична особа-підприємець, громадянин-підприємець, позбавлення статусу підприємия фізичною особою, припинення суб'єктів господарювання, державна реєстрація, ліквідація.

\section{ВСТУП}

Фізична особа-підприємець є однією з організаційноправових форм здійснення підприємницької діяльності, яка має широке застосування у практиці господарювання і займає вагоме місце у структурі товаровиробників національної економіки. Одним з елементів правового статусу фрізичної особи-підприємця є умови позбавлення такого статусу фізичною особою. На жаль, ні Господарський кодекс України [1] (далі - ГК України), ні Цивільний кодекс України [2] (далі - ЦК України) не регулю- 
ють ці питання. Актуальним є завдання внесення змін до ГК України (або прийняття його оновленого варіанта), і як частина цього завдання - належне правове забезпечення припинення суб'єктів господарювання. У правовій літературі значна увага приділяється питанням припинення суб'єктів господарювання-юридичних осіб у силу більшого обсягу нормативного матеріалу, різноманітності організаційно-правових форм юридичних осіб, складнішої процедури їхнього припинення. Цій проблематиці присвячено праці О. М. Зубатенко, Л. М. Дорошенко, В. С. Щербини, П. О. Повара, І. В. Спасибо-Фатєєвої, О. Р. Кібенко, Ю. М. Юркевич, О. Скороспис, В. О. Хоменко та ін. Разом із тим вимагають наукового опрацювання та висвітлення окремі проблеми припинення фрізичної особи-підприємця, які, на нашу думку, недостатньо висвітлені у правових дослідженнях. Однією з таких проблем є проблема термінологічного та понятійного апарату правового регулювання припинення фізичної особи-підприємця.

Метою статті $€$ визначення обсягу та змісту понятійно-термінологічного апарату правового регулювання припинення фрізичної особи-підприємця, розмежування основних і суміжних понять, вироблення теоретичних положень щодо розвитку та вдосконалення понятійного-термінологічного апарату та формулювання практичних пропозицій щодо вдосконалення законодавства та практики правозастосування.

Методологія дослідження полягає у застосуванні історичного методу для виявлення особливостей розвитку та закріплення у законодавстві термінологічного та понятійного апарату; у застосуванні системного та структурного методів, методів аналізу та синтезу, інших формального-логічних процедур під час визначення обсягу, змісту, співвідношення основних термінів і понять припинення фізичної особи-підприємця.

\section{ВИКЛАД ОСНОВНОГО МАТЕРІАЛУ}

Історичні аспекти вживання термінології у законодавстві України. Термін "припинення підприємницької діяльності" перейшло у сучасне законодавство із Закону УРСР "Про підприємництво" від 07.02.1991р., у якому ст. 11 була присвячена припиненню підприємницької діяльності [3]. У первісній редакції цього закону містилися норми щодо державної реєстрації підприємництва (у розумінні реєстрації суб'єктів підприємницької діяльності), проте не було згадки про державну реєстрацію припинення суб'єктів підприємницької діяльності. Законом № 2697-12 від 15.10.92 р. [4] статтю 8 Закону України "Про підприємництво" викладено у новій редакції 3 назвою "Державна реєстрація підприємництва", якою встановлено інститут скасування державної реєстрації. Зокрема, встановлювалося, що скасування державної реєстрації припиняє підприємницьку діяльність і $€$ підставою для здійснення заходів щодо ліквідації підприємця як суб'єкта підприємницької діяльності (ч. 11 ст.8 Закону України "Про підприємництво" у редакції від 03.12.1992р.) [5]. Вживання терміну "ліквідація", а також аналіз інших норм та редакцій Закону України "Про підприємництво" показує, що законодавець при викладенні правових положень орієнтувався переважно на фрігуру юридичних осіб. Уявляється, що причиною цього були наслідки радянського періоду, за якого громадянам не дозволялося займатися підприємницькою діяльністю, і у сфері господарювання панували господарські організації. Відтак, у центрі уваги законодавця були саме юридичні особи, які превалювали у структурі суб'єктів господарювання того періоду, тоді як Законом України "Про підприємництво" створювалися законодавчі підстави для запровадження у новітньому періоді розвитку України та її економіки такої організаційної форми господарювання, як громадянин-підприємець. Навіть термінологія позначення цієї форми ґрунтувалася на протиставленні юридичній особі: у Законі України "Про підприємництво" в редакції від 03.12.1992 р. окремо згадані "підприємці-громадяни, які здійснюють свою діяльність без створення юридичної особи" [5, ст. 8].

Згодом у результаті кодифікації господарського законодавства термін "скасування державної реєстрації" було вжито у ГК України (у його первісній редакції ст. 59, $247,248)$. Як і в попередньому законодавстві, це поняття стосувалося значною мірою лише суб'єктів господарювання-юридичних осіб. Без чіткого розмежування застосовувалися терміни "припинення підприємницької діяльності" у ст. 51 ГК (у цій статті знайшли відображення приписи ст. 11 Закону України "Про підприємництво") та "припинення діяльності суб'єкта господарювання" у ст. 59 ГК України (первісна редакція цієї статті була розрахована лише на суб'єктів господарювання-юридичних осіб. Зазначена стаття викладена у новій редакції в редакції Закону від 13.05.2014 р. [6] з назвою "Припинення суб'єкта господарювання" і на сьогодні є відсильною).

Новели з цього питання були привнесені Законом України "Про державну реєстрацію юридичних осіб, фізичних осіб-підприємців та громадських формувань" від 15.05.2003 р. [7] (далі - Закон України про реєстрацію), у якому замість скасування державної реєстрації були передбачені такі реєстраційні дії, як державна реєстрація припинення юридичної особи та державна реєстрація припинення підприємницької діяльності фозичними особами-підприємиями. Таким чином, термін "скасування державної реєстрації" не знайшов нормативного підкріплення у зазначеному спеціальному законі і відтак перейшов у категорію застарілих. Проте оновлення термінології інших правових актів розтягнулося в часі та не завжди проходило якісно. Для прикладу, лише 2010 р. законодавець шляхом внесення змін до ГК України відреагував на новели Закону України про реєстрацію, однак якість нормотворення була невисокою і відповідні зміни до ГК України містили недоліки. Так, відповідно до змін, внесених згідно із Законом № 2756 від 02.12.2010 р. [8] ч. 7 ст. 59 ГК України встановлювала, що "скасування державної реєстрації позбавляє суб'єкта господарювання статусу юридичної особи і $є$ підставою для вилучення його 3 державного реєстру. Суб'єкт господарювання вважається ліквідованим із дня внесення до державного реєстру запису про припинення його діяльності. Такий запис вноситься лише після затвердження ліквідаційного балансу відповідно до вимог цього Кодексу та подання головою ліквідаційної комісії або уповноваженою ним особою документів для проведення державної реєстраиії припинення юридичної особи або припинення діяльності фрізичною особою-підприємцем у порядку, визначеному Законом України "Про державну реєстрацію юридичних осіб і фрізичних осіб-підприємців" (курсивом виділено нами. - Авт.). Таким чином, у цій статті поєднувалося і застаріле поняття скасування державної реєстрації з дією вилучення з реєстру, і нове - державна реєстрація припинення юридичної особи або припинення діяльності фрізичною особою-підприємцем, установлене Законом України про реєстрацію. Ця норма є також ілюстрацією неврахування особливостей правового статусу фізичної особи-підприємця. Норма стосується юридичних осіб, але в її змісті спливає згадка про проведення державної реєстрації припинення діяльності фрізичною особою-підприємцем.

Норми із застарілою термінологією існують у законодавстві і сьогодні. Так, згідно із пунктом 3 ч. 2 Закону 
України "Про організаційно-правові основи боротьби 3 організованою злочинністю" від 30.06.1993 р. [9] за матеріалами оперативно-розшукової діяльності та кримінального провадження спеціальні підрозділи по боротьбі з організованою злочинністю мають право подавати до суду заяви про скасування реєстрації і припинення діяльності суб'єктів підприємництва. Наведені норми повинні бути приведені у відповідність із положеннями законодавства: мова може йтися про заяви щодо ліквідації юридичних осіб та позбавлення статусу підприємця фрізичною особою.

Таким чином, проглядається логічний ряд розвитку понятійно-термінологічного апарату, що бере початок від Закону УРСР "Про підприємництво" від 07.02.1991 р., де було врегульовано питання припинення підприємницької діяльності, які потім були доповнені поняттям скасування державної реєстрації i, насамкінець, Законом України про реєстрацію останнє замінено на державну реєстрацію припинення підприємницької діяльності фрізичними особами-підприємцями.

Стан сучасного законодавства. Положення, що визначають умови та порядок позбавлення статусу підприємця фрізичною особою, містяться у нормах Закону України про реєстрацію. Цей закон уводить у нормативний обіг і відповідний понятійно-термінологічний апарат. Недоліком законодавства є те, що ці питання не врегульовані у кодифікованих актах - ГК України та ЦК України [10, с. 45-46; 11, с. 185]. Слід зауважити, що попередні редакції положень ГК України відрізнялися більш системним підходом. У ньому передбачалися загальні норми, присвячені припиненню суб'єктів господарювання, хоча і з недостатньою увагою до питань позбавлення статусу підприємця фрізичною особою. Не можна визнати вдалим вихолощення змісту ГК України, шляхом виключення статей щодо припинення суб'єктів господарювання; викладення ст. 59 ГК України як бланкетної норми. Загальні положення щодо позбавлення статусу підприємця фрізичною особою повинні бути передбачені у кодифікованому акті господарського законодавства - у чинному ГК України або його оновленому варіанті. Зокрема, у ньому має бути закріплено відповідні термінологія та поняття, пов'язані з позбавленням статусу підприємця фізичною особою, умови та порядок такого позбавлення, його правові наслідки. Зазначені питання $€$ складовою правового статусу фізичної особипідприємця, як різновиду суб'єкта господарювання, а відтак, з урахуванням предмету регулювання нормативних актів вони повинні врегульовуватися у ГК України. Закон України про реєстрацію має предметом регулювання відносини з державної реєстрації. Такі відносини відрізняються особливим суб'єктним складом - за участі державного реєстратора, що вчиняє у визначеному цим законом порядку реєстраційні дії. Зважаючи на це, Закон України про реєстрацію не повинен собою визначати елементи правового статусу суб'єктів господарювання. Норми щодо державної реєстрації, які пов'язані з набуттям і позбавленням правового статусу підприємця фрізичною особою (як і суб'єктів господарювання інших організаційно-правових форм) повинні ґрунтуватися на нормах закону, що визначає їхній правовий статус, як суб'єктів підприємництва. I якщо щодо набуття статусу йдеться у ч. 1 ст. 128 ГК України, ч. 2 ст. 50 ЦК України, то стосовно позбавлення статусу у цих кодексах - лакуна. Зауважимо, що дотримання викладених засад проглядалися у логіці внесення змін до ЦК Законом України від 19.05.2011 р. № 3384 [12], яким ЦК України був доповнений ст. 50-1 "Обов'язки фрізичної особи-підприємця за зобов'язан- нями, пов'язаними з припиненням її підприємницької діяльності". Пізніше, у силу зміни концепції правового регулювання позбавлення статусу підприємця фрізичною особою, законодавець Законом України від 13.05.2014 р. № 1258 [6] виключив зазначену статтю.

Неврегульованість у ГК України (чи іншому кодифрікованому акті у сфері підприємництва) цих питань, на нашу думку, зумовлює такі негативні наслідки на практиці, як застосування термінів-замінників, що не мають нормативного підґрунтя, наприклад, "ліквідація фрізичної особи-підприємця". Безумовним досягненням у сфрері надання державних послуг в електронній формі $\epsilon$ створення та впровадження в експлуатацію Єдиного державного вебпорталу електронних послуг - портал Дія. На жаль, у ньому для позначення відповідної адміністративної послуги вживається термін "закриття ФОП" [13], замість легально визначеного. У такій підміні правової термінології іншими технічними термінами-аналогами, її спрощення для ніби легшого сприйняття суб'єктами правозастосування, криються негативні тенденції у правозастосовній юридичній техніці.

Як випливає з положень п. 4 ч. 1 ст. 1 Закону України про реєстрацію, поняття державної реєстрації включає у себе, зокрема й офіційне визнання шляхом засвідчення державою факту позбавлення статусу підприємця фрізичною особою. Державна реєстрація такого фракту відбувається шляхом внесення до Єдиного державного реєстру відповідного запису. Згідно із ч. 9 ст. 4 зазначеного Закону фрізична особа-підприємець позбавляється статусу підприємця з дати внесення до Єдиного державного реєстру запису про державну реєстрацію припинення підприємницької діяльності цією фізичною особою. В інших нормах Закону України про реєстрацію вживають лише термін "державна реєстрація припинення підприємницької діяльності" (ст. 11, 13, 18, 25, 29, 34).

Наведена норма ч. 9 ст. 4 Закону України про реєстрацію є відображенням подвоєння термінології: 3 одного боку засвідчується факт позбавлення статусу підприємця фізичною особою, а з іншого, у цьому випадку вноситься запис про припинення підприємницької діяльності чією фрізичною особою. Хоча логічно запис має відображати у своїй назві той фракт, який ним підтверджується. Відповідно реєстраційна дія повинна називатися "державна реєстрація позбавлення статусу підприємця фізичною особою". Як варіант, можна запропонувати "державна реєстрація припинення фізичної особи-підприємця" (щодо поняття "припинення фізичної особи-підприємця" йдеться далі).

Як закріплено у ч. 4 ст. 18 Закону України про реєстрацію для державної реєстрації припинення підприємницької діяльності фрізичної особи-підприємия подається один із таких документів: 1) заява про державну реєстрацію припинення підприємницької діяльності фрізичної особи - підприємця за ії рішенням - у разі державної реєстрації припинення підприємницької діяльності фрізичної особи - підприємця за її рішенням; 2) ксерокопія свідоцтва про смерть фізичної особи, судове рішення про визнання фрізичної особи безвісно відсутньою - у разі державної реєстрації припинення підприємницької діяльності фрізичної особи - підприємця у зв'язку з її смертю, визнанням її безвісно відсутньою або оголошенням померлою. Таким чином, законодавець розрізняє два випадки державної реєстрації припинення підприємницької діяльності фрізичної особи - підприємця: 1) за їі рішенням; 2) у зв'язку з ії смертю, визнанням ії безвісно відсутньою або оголошенням померлою. Державний реєстратор під час проведення державної реєстрації припинення підприємницької діяльності фізичної особи - підприємця 
у зв'язку з її смертю або оголошенням її померлою обов'язково використовує відомості Державного реєстру актів цивільного стану громадян шляхом безпосереднього доступу до нього [7, ч. 3 ст. 6].

Розмежування понять. Виникає теоретичне завдання розмежування понять "позбавлення статусу підприємця фрізичною особою" та "припинення підприємницької діяльності фрізичною особою-підприємцем", та інших, похідних і суміжних з ними, визначення співвідношення між ними.

Стосовно суб'єктів господарювання - господарських організацій (юридичних осіб) - у правовій літературі звертається увага на необхідність розрізнення понять "припинення суб'єкта господарювання" та "припинення господарської діяльності суб'єкта господарювання", які не є тотожними [10, с. 45; 11, с. 188-189]. На нашу думку, у випадку фрізичних осіб-підприємців слід розрізняти правові поняття "позбавлення статусу підприємця фрізичною особою" та "припинення підприємницької діяльності", які не $€$ тотожними і мають самостійне значення, а відтак законодавство із цього питання потребує вдосконалення.

Розглянемо декілька ситуацій, які демонструють відмінності між ними (зазначеними поняттями).

1. Фізична особа-підприємець фрактично припинила свою підприємницьку діяльність. Мотивом такого рішення і дій можуть бути різноманітні обставини: (а) зовнішнього характеру (стан ринку, на якому він здійснює діяльність; запровадження обмежень, що ускладнюють чи унеможливлюють здійснення діяльності; втрата майна тощо), (б) внутрішнього характеру (стан здоров'я, утрата бажання займатися підприємницькою діяльністю, зміна орієнтирів у житті та цілей діяльності тощо). У разі фактичного припинення підприємницької діяльності фрізична особа-підприємець має право звернутися до органу державної реєстрації для надання йому послуги 3 державної реєстрації припинення підприємницької діяльності, наслідком якої $€$ позбавлення статусу підприємця фрізичною особою.

Отже, припинення підприємницької діяльності фрізичної особи може відбутися до державної реєстрації припинення підприємницької діяльності фізичної особипідприємця, проте лише державна реєстрація такого факту (стану) призводить до позбавлення статусу підприємця фрізичною особою. Інакше кажучи, фрізична особа-підприємець припиняє діяльність і позбавляється статусу підприємця.

2. Ситуація, яка пов'язана з перервою у здійсненні підприємницької діяльності, коли фрізична особапідприємець протягом певного періоду не здійснює підприємницької діяльності, але залишається у статусі підприємця. Для її позначення іноді вживають терміни "тимчасове припинення", "призупинення" підприємницької діяльності. Недосконале врегулювання пов'язаних із цим відносин зумовило виникнення й існування у нашій країні проблеми так званих "сплячих" фрізичних осібпідприємців. Суть ії полягає у тому, що до внесення змін у законодавство щодо сплати єдиного соціального внеску (далі - ЄСВ), фрізична особа-підприємець могла призупинити здійснення підприємницької діяльності, продовжуючи перебувати у статусі підприємця, у цьому разі не виникало зобов'язань щодо сплати ЄСВ. 2017 р. введено в дію норми, що зобов'язали певні категорії фрізичних осіб-підприємців, які не отримують дохід від діяльності, з 01.01.2017 р. сплачувати ЄСВ [14; 15]. На вирішення проблем "сплячих" фрізичних осіб-підприємців держава змушена була прийняти спеціальні закони, що передбачали заходи щодо списання заборгованості стосовно окремих категорій фізичних осіб-підприємців, які не отримували доходу [16; 17].

3. У разі здійснення лише ліцензованого виду господарської діяльності зупинення й анулювання відповідної ліцензії матиме наслідком припинення (призупинення) підприємницької діяльності, але із збереженням статусу підприємця.

4. Державна реєстрація припинення підприємницької діяльності фрізичної особи-підприємця може бути здійснена стосовно особи, яка перебуває в активній підприємницькій діяльності, принаймні до дати внесення відповідного запису до Єдиного державного реєстру. У такому випадку наслідком державної реєстрації, окрім (1) втрати статусу підприємця, $€$ (2) обов'язок такої фрізичної особи припинити підприємницьку діяльність.

Для порівняння 3 юридичною особою у випадку її припинення вона припиняє існування як суб'єкт права, а відтак припиняється і діяльність такого суб'єкта (зокрема і підприємницька). У випадку ж фрізичної особи, яка продовжує жити, позбавлення ії̈ статусу підприємця має наслідки у її правовому статусі, і припинення нею підприємницької діяльності є виявом її вольової поведінки або в силу (1) - прийнятого нею рішення про позбавлення статусу підприємця та звернення до органу державної реєстрації (у випадку добровільного позбавлення) - правовою фрормою таких дій є реалізація суб'єктивного права на припинення підприємницької діяльності, або в силу (2) застосованого до неї державного примусу (у випадку примусового позбавлення статусу). Правомірність поведінки в останньому випадку полягає у виконанні юридичного обов'язку припинення підприємницької діяльності фрізичною особою, позбавленою статусу підприємця. Поведінка може бути і неправомірною: фрізична особа, попри державну реєстрацію припинення ії підприємницької діяльності, продовжує підприємницьку діяльність, яка визнається незаконною. Стаття 164 Кодексу України про адміністративні порушення передбачає адміністративну відповідальність за провадження господарської діяльності без державної реєстрації як суб'єкта господарювання [18].

5. Чинне законодавство містить і інші норми, які стосуються ситуації здійснення підприємницької діяльності фрізичною особою без статусу підприємця. Так, згідно із ч. 3 ст. 50 ЦК України, якщо особа розпочала підприємницьку діяльність без державної реєстрації, уклавши відповідні договори, вона не має права оспорювати ці договори на тій підставі, що вона не є підприємцем. Уявляється, що в силу розширеного тлумачення ця норма повинна застосовуватися і до тих випадків, коли здійснено державну реєстрацію припинення підприємницької діяльності - особа втратила статус підприємця, але нею фактично здійснюється така діяльність з укладенням відповідних договорів.

6. Одними з підстав здійснення державної реєстрації припинення підприємницької діяльності фрізичної особи-підприємця згідно із ч. 4 ст. 18 Закону України про реєстрацію $є$ смерть особи й оголошення її померлою. У момент смерті припиняється ії життєдіяльність, зокрема і підприємницька діяльність. Згідно із ч. 4 ст. 25 ЦК України у цей момент припиняється і цивільна правоздатність фрізичної особи. Правові наслідки оголошення фрізичної особи померлою прирівнюються до правових наслідків, які настають у разі смерті (ч. 1 ст. 47 ЦК України). Таким чином, внесення після смерті особи (у якої з погляду права вже припинена цивільна правоздатність разом із правом здійснення підприємницької діяльності) запису до Єдиного державного реєстру про припинення підприємницької діяльності такої 
особи не має наслідком позбавлення її статусу підприємця. У такому випадку значення державної реєстрації припинення підприємницької діяльності фізичної особипідприємця зводиться до забезпечення за допомогою Єдиного державного реєстру збирання, обліку та надання достовірної інформації про фрізичних осібпідприємців [19, с. 78].

Таким чином, слід констатувати різну правову природу фрактів:

1) фракт припинення підприємницької діяльності є відображенням змін у поведінці суб'єкта права. Така поведінка може бути у формі реалізації суб'єктивного права або виконання юридичного обов'язку;

2) фракт позбавлення статусу підприємця є відображенням змін у правовому статусі суб'єкта права. Позбавлення статусу підприємця визначає неправомірність здійснення підприємницької діяльності в подальшому.

Неврахування цього лежить в основі невдалої редакції ст. 51 ГК України, що визначає підстави припинення підприємницької діяльності (як зазначалося вище, норми цієї статті перейшли із ст. 11 Закону України "Про підприємництво"). Закріплені у ній підстави можуть розглядатися як підстави припинення підприємницької діяльності (1) із збереженням статусу підприємця (наприклад, у разі закінчення строку дії ліцензії) та (2) із позбавленням такого статусу (наприклад, у разі припинення існування підприємця, на підставі рішення суду).

Враховуючи викладене, пропонуємо уникнути дублювання в нормативній термінології та позбутися доволі умовного терміна "державна реєстрація припинення підприємницької діяльності" на користь терміна "державна реєстрація позбавлення статусу підприємця фрізичною особою".

Позбавлення статусу підприємця фрізичною особою означає втрату особою права на займання підприємницькою діяльністю. Державна реєстрація позбавлення статусу підприємця фрізичною особою визначає дії держави щодо офріційного засвідчення факту позбавлення статусу підприємця фрізичною особою.

Поняття "припинення фізичної особи-підприємця". Питання застосування та визначення цього поняття $€$ дискусійним. Таке поняття $€$ привабливим із погляду уніфікації термінології, коли зазначене поняття перебуватиме у структурному зв'язку з родовим поняттям "припинення суб'єкта господарювання" та однопорядковим - "припинення суб'єкта господарювання-юридичної особи". Пропонуємо під припиненням фізичної особи-підприємця розуміти позбавлення фрізичної особи статусу підприємця фрізичною особою в результаті державної реєстрації такого стану (позбавлення статусу підприємця фрізичною особою у вузькому значенні) або втрату нею цивільної правоздатності в момент смерті чи в день оголошення ії померлою. Таким чином, враховуються різні обставини та правова природа втрати фізичною особою права на зайняття підприємницькою діяльністю, різні правові наслідки. У першому випадку - внаслідок державної реєстрації фракту позбавлення підприємця статусу підприємця фізичною особою - зберігається цивільна правоздатність такої особи і їі майнові зобов'язання, що виникли під час здійснення підприємницької діяльності. У другому випадку - припинення цивільної правоздатності у цілому внаслідок смерті чи оголошення її померлою з наслідками, що визначаються спадковим правом. Іншим варіантом $є$ вживання позбавлення статусу підприємця фізичною особою у широкому значенні, яке охоплює собою два визначені вище випадки
3 метою усунення прогалин у правовому регулюванні питань припинення фрізичних осіб-підприємців кодифікованим актом господарського законодавства, пропонуємо ст. 128 ГК України доповнити положеннями, згідно з якими громадянин втрачає статус підприємця в день внесення запису про державну реєстрацію позбавлення статусу підприємця фрізичною особою або в момент її смерті чи в день оголошення ії̈ померлою.

Термін "ліквідація". Стосовно фрізичної особипідприємця не можуть бути застосовані терміни "ліквідація" та "реорганізація", які вживаються для позначення форм припинення виключно суб'єктів господарювання-господарських організацій (юридичних осіб). Слід розрізняти особливості термінології та визначення понять згідно з актами господарського законодавства й інших галузей законодавства, які мають свою спеціальну сферу застосування, особливий суб'єктний склад, що $є$ відображенням особливостей правового регулювання певних галузей права. Так, у Податковому кодексі України щодо платників податків застосовано термін ліквідація платника податків. Згідно з п. 97.1 ст. 97 Податкового кодексу України під ліквідацією платника податків розуміється ліквідація платника податків як юридичної особи або державна реєстрація припинення підприємницької діяльності фрізичної особи чи реєстрація у відповідному уповноваженому органі припинення незалежної професійної діяльності фрізичної особи (якщо така реєстрація була умовою ведення незалежної професійної діяльності), унаслідок якої відбувається закриття їхніх рахунків та/або втрата їхнього статусу як платників податків відповідно до законодавства [20].

Ми не підтримуємо позицію можливості застосування терміну "ліквідація" стосовно фрізичної особипідприємця. Насамперед, у силу різного змісту правового регулювання, юридичних підстав (умов), процесуально-правових дій і наслідків, які мають місце при ліквідації юридичних осіб як суб'єктів господарювання, 3 одного боку, та припиненні фрізичної особи-підприємця, з іншого. У випадку ліквідації юридичних осіб відбувається припинення існування їх як суб'єктів права та припинення правовідносин за їхньої участі без правонаступництва. У випадку позбавлення статусу підприємця фрізичною особою (у вузькому розумінні) правовідносини за їх участі не припиняються, а випадку смерті фрізичної особи-підприємця виникають спадкові правовідносини, яким властиве універсальне правонаступництво. Якщо вживати у таких випадках термін "ліквідація", то тоді розмиватиметься традиційне розуміння відповідного поняття як способу припинення лише юридичних осіб без правонаступництва. Відповідно до дихотомічного поділу за критерієм правонаступництва ліквідація (відсутнє правонаступництво) традиційно класифрікується поряд із реорганізацією (присутнє правонаступництво) як спосіб припинення саме суб'єктів господарювання-юридичних осіб. У силу цього не можна визнати вдалим визначення поняття ліквідації суб'єкта господарювання як родового, що у свою чергу включатиме видові поняття ліквідації юридичної особи та ліквідації фізичної особи-підприємця. У такому випадку виникає потреба розкриття змісту останнього через уже розглянуте поняття "припинення фрізичної особипідприємця" або "позбавлення статусу підприємця фізичною особою". Логічним $€$ визначення як родового поняття "припинення суб'єкта господарювання", яке в силу поділу суб'єктів господарювання згідно із ч. 2 ст. 55 ГК України, охоплює собою два видові поняття: (1) припинення фрізичної особи-підприємця (як варіант, позбавлення статусу підприємця фрізичною особою у 
його широкому значенні) та (2) припинення суб'єкта господарювання-юридичної особи. Останнє включає в себе два підвидові поняття: (2.1) ліквідація суб'єкта господарювання-юридичної особи та (2.2) реорганізація суб'єкта господарювання-юридичної особи.

\section{висновки}

1. Правова природа (1) факту припинення підприємницької діяльності та (2) фракту позбавлення статусу підприємця фрізичною собою $є$ різною. Перший $є$ відображенням змін у поведінці суб'єкта права. Така поведінка може бути у формі реалізації суб'єктивного права або виконання юридичного обов'язку. Другий $є$ відображенням змін у правовому статусі суб'єкта права. Позбавлення статусу підприємця визначає неправомірність здійснення підприємницької діяльності в подальшому.

Недоліком ст. 51 ГК України $є$ те, що у ній не розмежовуються й одночасно зазначаються підстави припинення підприємницької діяльності, які мають різну правову природу. Такі підстави можуть розглядатися як підстави припинення підприємницької діяльності (1) зі збереженням статусу підприємця та (2) з позбавленням такого статусу.

2. Термін "державна реєстрація припинення підприємницької діяльності фрізичною особою" має бути замінений на термін "державна реєстрація позбавлення статусу підприємця фрізичною особою" або як варіант "державна реєстрація припинення фрізичної особипідприємця". Відповідні зміни повинні бути внесені до чинного Закону про реєстрацію.

3. Запропоновано внести зміни до п. 3 ч. 2 Закону України "Про організаційно-правові основи боротьби 3 організованою злочинністю", у якому слова "заяви про скасування реєстрації і припинення діяльності суб'єктів підприємництва" замінити на слова "заяви про ліквідацію суб'єкта господарювання-юридичної особи або позбавлення статусу підприємця фізичною особою".

3. Загальні положення щодо припинення фрізичної особи-підприємця (позбавлення статусу підприємця фізичною особою у широкому розумінні) повинні встановлюватися у кодифікованому акті господарського законодавства - ГК України, або у його оновленому варіанті. Зокрема, у ньому мають закріплюватися відповідні термінологія та поняття, пов'язані з припиненням фізичної особи-підприємця.

Стосовно чинного ГК України запропоновано доповнити його ст. 128 новою частиною восьмою такого змісту: "8. Громадянин втрачає статус підприємця в день внесення запису про державну реєстрацію позбавлення статусу підприємця фрізичною особою або в момент її смерті чи в день оголошення ії померлою".

4. Запропоновано під припиненням фрізичної особипідприємця розуміти позбавлення фрізичної особи статусу підприємця фізичною особою в результаті державної реєстрації такого стану (позбавлення статусу підприємця фрізичною особою у вузькому значенні) або втрату нею цивільної правоздатності в момент смерті чи в день оголошення ії̈ померлою.

Поняття "позбавлення статусу підприємця фрізичною особою" може вживатися у вузькому та широкому значеннях. У широкому значенні воно збігається з наведеним поняттям припинення фрізичної особи-підприємця.

5. Структурний зв'язок між основними поняттями щодо припинення суб'єктів господарювання полягає у визначенні як родового поняття "припинення суб'єктів господарювання", яке включає видові поняття "припинення фізичної особи-підприємця" ("позбавлення статусу підприємця фрізичною особою" у широкому значенні) та "припинення суб'єкта господарювання-юридичної особи". Термін "ліквідація" не варто вживати стосовно фрізичних осіб-підприємців.

Список використаних джерел:

1. Господарський кодекс України : Кодекс України від 16.01.2003 №436-15 [Електронний ресурс]. - Режим доступу: https://zakon.rada.gov.ua/ laws/show/436-15\#Теxt (дата звернення: 10.09.2021).

2. Цивільний кодекс України : Кодекс України від 16.01.2003 №435-15 [Електронний ресурс]. - Режим доступу: https://zakon.rada.gov.ua/laws/ show/435-15\#Text (дата звернення: 10.09.2021)

3. Про підприємництво : Закон Української РСР від 07.02.1991 №698-XII (в редакції від 07.02.1991) [Електронний ресурс]. - Режим доступу: https://zakon.rada.gov.ua/laws/show/698-12/ed19910207\#Техt (дата звернення: 10.09.2021)

4. Про внесення змін і доповнень до Закону Української РСР "Про підприємництво" : Закон України від 15.10.1992 №2697-XII [Електронний ресурс]. - Режим доступу: https://zakon.rada.gov.ua/laws/show/269712/ed19921015\#Техt (дата звернення: 10.09.2021).

5. Про підприємництво : Закон України від 07.02.1991 №698-XII (в редакції від 03.12.1992) [Електронний ресурс]. - Режим доступу: https://zakon.rada.gov.ua/laws/show/698-12/ed19921203\#Text (дата звернення: 10.09.2021)

6. Про внесення змін до деяких законодавчих актів України щодо спрощення процедури державної реєстрації підприємницької діяльності фізичних осіб-підприємців за заявницьким принципом : Закон України від 13.05.2014 №1258-VII [Електронний ресурс]. - Режим доступу: https://zakon.rada.gov.ua/laws/show/1258-18\#Text (дата звернення: 10.09.2021).

7. Про державну реєстрацію юридичних осіб, фрізичних осіб та громадських формувань : Закон України від 15.05.2003 №755-IV [Електронний ресурс]. - Режим доступу: https://zakon.rada.gov.ua/laws/show/ 755-15\#Техt (дата звернення: 10.09.2021).

8. Про внесення змін до деяких законодавчих актів України у зв'язку з прийняттям Податкового кодексу України : Закон від 02.12.2010 №2756-VI https://zakon.rada.gov.ua/laws/show/2756-17/ed20110101\#Text (дата звернення: 10.09.2021).

9. Про організаційно-правові основи боротьби з організованою злочинністю : Закон від 30.06.1993 №3341-XII [Електронний ресурс]. Режим доступу: https://zakon.rada.gov.ua/laws/show/3341-12\#Техt (дата звернення: 10.09.2021)

10. Щербина В.С. Суб'єкти господарського права : монографія / В.С. Щербина. - К . : Юрінком Інтер, 2008.

11. Актуальні проблеми господарського права: навч.посіб. / за ред. В.С. Щербини. - К. : Юрінком Інтер, 2012.

12. Про внесення змін до деяких законодавчих актів України щодо спрощення процедур припинення юридичних осіб та підприємницької діяльності фрізичних осіб - підприємців за їх рішенням : Закон України від 19.05.2011 №3384-VI [Електронний ресурс]. - Режим доступу: https://zakon.rada.gov.ua/laws/show/3384-17\#Text (дата звернення: 10.09.2021)

13. Закриття ФОП : Державні послуги. Державний портал [Електронний ресурс]. - Режим доступу: https://diia.gov.ua/services/zakrittya-fop (дата звернення: 10.09.2021).

14. Про збір та облік єдиного внеску на загальнообов'язкове державне соціальне страхування : Закон України від 08.07.2010 №2464-VI Електронний ресурс]. - Режим доступу: https://zakon.rada.gov.ua/laws/ show/2464-17\#Text (дата звернення: 10.09.2021).

15. Чабаненко О. Що робити з ЄСВ-заборгованістю "сплячих" ФОП? [Електронний ресурс]. - Режим доступу: https://uz.ligazakon.ua/ua/ magazine article/EA014525 (дата звернення: 10.09.2021).

16.Про внесення змін до Закону України "Про збір та облік єдиного внеску на загальнообов'язкове державне соціальне страхування" щодо усунення дискримінації за колом платників : Закон України від 13.05.2020 №592-IX [Електронний ресурс]. - Режим доступу: https://zakon.rada.gov.ua/laws/show/592-IX\#Text (дата звернення: 10.09.2021).

17. Про внесення змін до Податкового кодексу України та інших законів України щодо соціальної підтримки платників податків на період здійснення обмежувальних протиепідемічних заходів, запроваджених з метою запобігання поширенню на території України гострої респіраторної хвороби COVID-19, спричиненої коронавірусом SARS-CoV-2: Закон України від 04.12.2020 №1072-IX [Електронний ресурс]. - Режим доступу: https://zakon.rada.gov.ua/laws/show/1072-20\#Text (дата звернення: 10.09.2021).

18. Кодекс України про адміністративні правопорушення : Кодекс України від 07.12.1984 №8073 [Електронний ресурс]. - Режим доступу: https://zakon.rada.gov.ua/laws/show/80731-10/paran1469\#n1469 (дата звернення: 10.09.2021)

19. Господарське право (Загальна частина) : підручник. За ред. В.С. Щербини, В.В. Рєзнікової. Київ. Вид-во Ліра-К. 2021

20. Податковий кодекс України : Кодекс України від 02.12.2010 №2755-VI [Електронний ресурс]. - Режим доступу: https://zakon.rada.gov.ua/ laws/show/2755-17\#Техt (дата звернення: 10.09.2021). 
References:

1. Hospodars'kyy kodeks Ukrayiny, Zakon Ukrayiny [The Commercial Code of Ukraine, Law of Ukraine] №436-15 (2003) https://zakon.rada.gov.ua/ laws/show/436-15\#Text (accessed 10.09.2921) (in Ukrainian).

2. Tsyvil'nyy kodeks Ukrayiny, Zakon Ukrayiny [The Civil Code of Ukraine, Law of Ukraine] №435-15 (2003) https://zakon.rada.gov.ua/laws/ show/435-15\#Text (accessed 10.09.2921) (in Ukrainian).

3. Pro pidpryyemnytstvo, Zakon Ukrayiny [On Entrepreneurship, Law of Ukraine] №698-XII (1991) https://zakon.rada.gov.ua/laws/show/698-12/ ed19910207\#Text (accessed 10.09.2021) (in Ukrainian)

4. Pro vnesennya zmin i dopovnen' do Zakonu Ukrayins'koyi RSR "Pro pidpryyemnytstvo", Zakon Ukrayiny [On Amendments and Addenda to the Law of the Ukrainian SSR "On Entrepreneurship", Law of Ukraine] №2697XII (1992) https://zakon.rada.gov.ua/laws/show/2697-12/ed19921015\#Text (accessed 10.09.2021) (in Ukrainian)

5. Pro pidpryyemnytstvo, Zakon Ukrayiny [On Entrepreneurship, Law of Ukraine] №698-XII (1992) https://zakon.rada.gov.ua/laws/show/698-12/ ed19921203\#Text (accessed 10.09.2021) (in Ukrainian).

6. Pro vnesennya zmin do deyakykh zakonodavchykh aktiv Ukrayiny shchodo sproshchennya protsedury derzhavnoyi reyestratsiyi pidpryyemnyts'koyi diyal'nosti fizychnykh osib-pidpryyemtsiv za zayavnyts'kym pryntsypom, Zakon Ukrayiny [On Amendments to Certain Legislative Acts of Ukraine to Simplify the Procedure for State Registration of Termination of Entrepreneurial Activity of Natural Persons Entrepreneurs Using the Declarative Principle, Law of Ukraine] №1258-VII (2014) https://zakon.rada.gov.ua/laws/show/1258-18\#Text (accessed 10.09.2021) (in Ukrainian)

7. Pro derzhavnu reyestratsiyu yurydychnykh osib, fizychnykh osib ta hromads'kykh formuvan', Zakon Ukrayiny [On State Registration of Legal Entities, Natural Persons - Entrepreneurs and Public Formations, Law of Ukraine] №755-IV (2003) https://zakon.rada.gov.ua/laws/show/755-15\#Text (accessed 10.09.2021) (in Ukrainian)

8. Pro vnesennya zmin do deyakykh zakonodavchykh aktiv Ukrayiny u zv'yazku z pryynyattyam Podatkovoho kodeksu Ukrayiny, Zakon Ukrayiny [On Amendments to Some Legislative Acts of Ukraine in Connection with the Adoption of the Tax Code of Ukraine, Law of Ukraine] №2756-VI (2010) https://zakon.rada.gov.ua/laws/show/2756-17/ed20110101\#Text (accessed 10.09.2021) (in Ukrainian).

9. Pro orhanizatsiyno-pravovi osnovy borot'by $z$ orhanizovanoyu zlochynnistyu, Zakon Ukrayiny [On Organizational Legal Principles of Struggle against the Organized Crime, Law of Ukraine] №3341-XII (1993) https://zakon.rada.gov.ua/laws/show/3341-12\#Text (accessed 10.09.2021) (in Ukrainian)

10. Shcherbyna, V.S. (2008) Sub'yekty hospodars'koho prava [Subjects of economic law]. Kyiv: Yurinkom Inter (in Ukrainian).

11. Aktual'ni problemy hospodars'koho prava (2012) [Current issues of business law]. Kyiv: Yurinkom Inter (in Ukrainian).

12. Pro vnesennya zmin do deyakykh zakonodavchykh aktiv Ukrayiny shchodo sproshchennya protsedur prypynennya yurydychnykh osib ta pidpryyemnyts'koyi diyal'nosti fizychnykh osib - pidpryyemtsiv za yikh rishennyam, Zakon Ukrayiny [ About Modification of Some Legislative Acts of Ukraine Concerning Simplification of Procedures of the Termination of
Legal Entities and Business Activity of Physical Persons - Businessmen by Their Decision, Law of Ukraine] №3384-VI (2011) https://zakon rada.gov ua/ laws/show/3384-17\#Text (accessed 10.09.2021) (in Ukrainian).

13. Zakryttya FOP : Derzhavni posluhy. Derzhavnyy portal [Closing of Natural Persons - Entrepreneurs: Public services. State portal] https://diia.gov.ua/services/zakrittya-fop (accessed 10.09.2021) (in Ukrainian)

14. Pro zbir ta oblik yedynoho vnesku na zahal'noobov"yazkove derzhavne sotsial'ne strakhuvannya, Zakon Ukrayiny [On Collection and Registration of the Single Contribution for Mandatory State Social Insurance, Law of Ukraine] №2464-VI (2010) https://zakon.rada.gov.ua/ laws/show/2464-17\#Text (accessed 10.09.2021) (in Ukrainian).

15. Chabanenko $O$. Shcho robyty $Z$ YESV-zaborhovanistyu "splyachykh" FOP? (2021) [What to do with the SRS-debt of "sleeping" natural persons - entrepreneurs private individuals?] https://uz.ligazakon.ua/ ua/magazine_article/EA014525 (accessed 10.09.2021) (in Ukrainian).

16. Pro vnesennya zmin do Zakonu Ukrayiny "Pro zbir ta oblik yedynoho vnesku na zahal'noobov"yazkove derzhavne sotsial'ne strakhuvannya" shchodo usunennya dyskryminatsiyi za kolom platnykiv, Zakon Ukrayiny [ On Amendments to the Law of Ukraine "On Collection and Accounting of the Single Contribution for Compulsory State Social Insurance" to Eliminate Discrimination by Payers, Law of Ukraine] №592-IX (2020) https://zakon.rada.gov.ua/laws/show/592-IX\#Text (accessed 10.09.2021) (in Ukrainian).

17. Pro vnesennya zmin do Podatkovoho kodeksu Ukrayiny ta inshykh zakoniv Ukrayiny shchodo sotsial'noyi pidtrymky platnykiv podatkiv na period zdiysnennya obmezhuval'nykh protyepidemichnykh zakhodiv, zaprovadzhenykh z metoyu zapobihannya poshyrennyu na terytoriyi Ukrayiny hostroyi respiratornoyi khvoroby COVID-19, sprychynenoyi koronavirusom SARS-CoV-2, Zakon Ukrayiny [On Amendments to the Tax Code of Ukraine and Other Laws of Ukraine on Social Support of Taxpayers for the Period of Restrictive Anti-Epidemic Measures Introduced to Prevent the Spread of Acute Respiratory Disease COVID-19 Caused by SARS-CoV-2 Coronavirus in Ukraine, Law of Ukraine] №1072-IX (2020) https://zakon.rada.gov.ua/laws/show/1072-20\#Text (accessed 10.09.2021) (in Ukrainian).

18. Kodeks Ukrayiny pro administratyvni pravoporushennya, Zakon Ukrayiny [Code of Ukraine on Administrative Offenses, Law of Ukraine] №8073 (1984) https://zakon.rada.gov.ua/laws/show/80731-10/paran1469\#n1469 (accessed 10.09.2021) (in Ukrainian).

19. Hospodars'ke pravo.Zahal'na chastyna (2021) Commercial law. General part. Kyiv, Lira-K (in Ukrainian).

20. Podatkovyy kodeks Ukrayiny, Zakon Ukrayiny [Tax Code of Ukraine, Law of Ukraine] №2755-VI (2010) https://zakon.rada.gov.ua/laws/ show/2755-17\#Text (accessed 10.09.2021) (in Ukrainian).

Received: $28 / 09 / 2021$ Accepted: $20 / 10 / 2021$

P. Povar, PhD (Law), Associate Prof.

Taras Shevchenko National University of Kyiv, Kyiv, Ukraine

\section{LEGAL REGULATION OF CESSATION OF A NATURAL PERSON-ENTREPRENEUR: CONCEPTUAL AND TERMINOLOGICAL PROBLEMS}

An important element of the legal status of a natural person-entrepreneur is the conditions for depriving him of the entrepreneur status. The purpose of the article is to determine the scope and content of the conceptual and terminological apparatus of legal regulation of a natural person-entrepreneur cessation, development of theoretical provisions and proposals for improving legislation and law enforcement practice. The research methodology is based on the application of historical, systemic, structural methods, methods of analysis, synthesis and other formal-logical procedures.

As a result of the study of the historical formation of Ukrainian legislation, a logical series of development of the conceptual and terminological apparatus of legislative acts is defined and highlighted. The necessity of enshrining in the codified act in the field of entrepreneurship general provisions on deprivation of the status of an entrepreneur by an individual, including the use of appropriate terminology and concepts, is substantiated.

Proposals have been formulated to supplement The Commercial Code of Ukraine with a norm on the loss of the entrepreneurial status by an individual. The distinction is made and the relations between the concepts of "termination of the natural person-entrepreneurial activity", "deprivation of a natural person of the entrepreneur status", "cessation of a natural person-entrepreneur", "cessation of the economic entity" are established.

The provisions on the legal nature of the fact of termination of entrepreneurial activity and the fact of deprivation of a natural person of the status of an entrepreneur have been studied and formulated. The shortcomings of the norms of the current legislation, which do not differentiate the grounds for termination of activity of different legal nature, have been identified and substantiated.

It is proposed to replace the term "state registration of cessation of natural person - entrepreneur activity" with the term "state registration of deprivation a natural person of the entrepreneurial status" and make appropriate changes in the legislation of Ukraine.

In the conclusion the inexpediency of using the term "liquidation" in relation to a natural person-entrepreneur is substantiated. The definition of the concept of "cessation of a natural person-entrepreneur" is formulated. The possibility of using the concept of " deprivation of a natural person of the status of an entrepreneur" in the narrow and broad sense is outlined. Provisions are formulated for the structural connection between the basic concepts of cessation of economic entities.

Keywords: cessation of the entrepreneurial activity, natural person-entrepreneur, citizen-entrepreneur, deprivation of a natural person of the status of an entrepreneur, cessation of economic entities, state registration, liquidation. 
Bulletin of Taras Shevchenko National University of Kyiv. Legal Studies, 2021; 4 (119): 70-74

УДК 342.5

DOI: https:doi.org/10.17721/1728-2195/2021/4.119-13
ISSN 1728-2195

(C) Taras Shevchenko National University of Kyiv,

Publishing center "Kyiv University", 2021

С. В. Прилуцький, д-р юрид. наук, доц ORCID ID: 0000-0002-5019-6975

Київський національний університет імені Тараса Шевченка, Київ, Україна

\section{ПРИНЦИП ПРИРОДНОГО СУДУ: АКТУАЛЬНІ ПРОБЛЕМИ ПРАВОРОЗУМІННЯ ТА ПРАВОЗАСТОСУВАННЯ В УКРАЇНІ}

2016 року у сm. 125 Основного Закону України з'явилося положення, яке передбачає, що відповідно до закону можуть діяти вищі спеціалізовані суди. Наповнюючи змістом ие формулювання, у ст. 31 Закону "Про судоустрій і статус суддів" (2016 р.) установлено, що у системі судоустрою діють вищі спеціалізовані суди як суди периої інстанції 3 розгляду окремих категорій справ. До цієї категорії судів нині належать Вищий суд із питань інтелектуальної власності та Вищий антикорупційний суд, діяльність яких започатковано відповідним законодавством.

Проте у політичних колах розгорнулася дискусія щодо конституційності вказаного суду й відповідно суб'єкт права на конституційне подання поставив під сумнів низку положень Закону "Про Вищий антикорупційний суд" і звернувся до Конституційного Суду України про визнання цього закону неконституційним повністю. У свою чергу, Конституційний Суд України розпочав судове конституційне провадження щодо цього питання.

Ознайомлення 3 правовою позицією суб'єкта конституційного подання вказує на те, що ключове питання цього конституційного провадження стосується наявності ознак "особливого суду" (у розумінні ч. 6 ст. 125 Конституції України) у механізмі законодавчого регулювання правового статусу Вищого антикорупційного суду.

3 метою пошуку об'єктивної відповіді на існуючу колізію виникла необхідність виокремлення ключових ознак "особливого суду". Для розв'язання такої прикладної проблеми автор статті звернувся до теоретичних і прикладних положень принципу природного суду, що і стало предметом дослідження цієї роботи.

Ключові слова: природний суд, право на справедливий суд, Вищий антикорупційний суд, особливий суд, надзвичайний суд.

\section{ВСТУП}

Після конституційної реформації 2016 р., у ст. 125 Основного Закону з'явилося положення такого змісту: "Відповідно до закону можуть діяти вищі спеціалізовані суди". Розвиваючи це конституційне положення, у ст. 31 Закону "Про судоустрій і статус суддів" (2016 р.) установлено, що у системі судоустрою діють вищі спеціалізовані суди як суди першої інстанції з розгляду окремих категорій справ. До цієї категорії судів нині належать Вищий суд із питань інтелектуальної власності та Вищий антикорупційний суд. 2018 р. законодавець ухвалив Закон "Про Вищий антикорупційний суд", а Законом "Про утворення Вищого антикорупційного суду" (2018 р.) започаткував створення цього суду.

Проте у політичних колах розгорнулася дискусія щодо конституційності цього суду й відповідно суб'єкт права на конституційне подання (49 народних депутатів) у конституційному поданні (№ 04-02/6-339 від 22 липня 2020 р.) [1] поставив під сумнів низку положень Закону "Про Вищий антикорупційний суд" і звернувся до Конституційного Суду України про визнання вказаного закону неконституційним повністю. У свою чергу, Конституційний Суд України розпочав судове конституційне провадження щодо цього питання ${ }^{4}$.

Детальне ознайомлення із правовою позицією суб'єкта конституційного подання вказує на те, що ключове питання цього конституційного провадження стосується наявності ознак "особливого суду" (у розумінні ч. 6 ст. 125 Конституції України) у механізмі законодавчого регулювання правового статусу Вищого антикорупційного суду.

3 метою пошуку об'єктивної відповіді на існуючу колізію, необхідним $€$ абстрактне виокремлення головних ознак "особливого" суду. І для розв'язання цієї прикладної проблеми, на мою думку, доречно передусім звернутись до концепції "природного суду", що й виступить ключовим предметом дослідження цієї роботи.

Міжнародні та зарубіжні критерії принципу природного суду. Принцип "природного суду (судді)" (icп. - juez natural) становить фундаментальну гаран-

4 Переглянути відкриту частину пленарного засідання можна на офріційному вебсайті Конституційного Суду України за посиланням: http://ccu.gov.ua/kategoriya/2020 тію права на справедливий судовий розгляд. Ідейні основи цього принципу вже можна побачити у Великій хартії вольностей (1215р.), які відображалися у "праві на суд рівних відповідно до законів країни" [2, с. 65]. Водночас, у період Великої французької революції принцип природного суду відображено у Конституції Франції (1791р.) [3], де встановлювалося, що громадяни не можуть бути позбавлені законної підсудності ніякими спеціальними указами, ні іншими розпорядженнями про передачу чи вилучення їхніх справ, крім випадків, передбачених законом.

На сьогоднішній день ідея природного суду відображена у положеннях ст. 14 Міжнародного пакту про громадянські й політичні права (далі - МПГПП), де встановлено, що всі особи є рівними перед судами і трибуналами і кожен має право у процесі розгляду будь-якого кримінального обвинувачення, пред'явленого йому, або у разі визначення його права та обов'язків у будь-якому цивільному процесі на справедливий i публічний розгляд справи компетентним, незалежним і безстороннім судом, створеним на підставі закону; а також у ст. 6 Конвенції про захист прав людини і основоположних свобод, яка встановлює право на справедливий суд, і передбачає, що кожен має право на справедливий і публічний розгляд його справи упродовж розумного строку незалежним і безстороннім судом, установленим законом, який вирішить спір щодо його прав та обов'язків цивільного характеру або встановить обґрунтованість будь-якого висунутого проти нього кримінального обвинувачення.

У сучасному розумінні, принцип природного суду означає, що жодна особа не може бути засуджена інакше, ніж звичайним, раніше встановленим, компетентним судом або суддею. Як наслідок цього принципу, не допускається створення екстрених, ad hoc, надзвичайних судів і судів, створених ex post facto (постфактум). Незважаючи на те, що принцип "природного суду (судді)" заснований на суміжному принципі рівності перед законом і судом, який означає, що закони не повинні бути дискримінаційними або застосовуватися суддями дискримінаційним чином, проте, як зазначає Комітет із прав людини, "право на рівність перед законом $і$ на рівний захист закону без будь-якої дискримінації не 